\title{
Glacially striated, soft sediment surfaces on late Paleozoic tillite at São Luiz do Purunã, PR
}

\author{
IVO TROSDTORF JR. ${ }^{1}$, MARIO L. ASSINE ${ }^{2}$, FERNANDO F. VESELY ${ }^{3}$, \\ ANTONIO C. ROCHA-CAMPOS ${ }^{4}$, PAULO R. DOS SANTOS ${ }^{4}$ and ALEXANDRE TOMIO ${ }^{4}$ \\ ${ }^{1}$ PETROBRAS S/A, Rua General Canabarro, 500 \\ 20271-900 Rio de Janeiro, RJ, Brasil \\ ${ }^{2}$ Instituto de Geociências e Ciências Exatas, UNESP, Avenida 24-A, 1515 \\ 13506-900 Rio Claro, SP, Brasil \\ ${ }^{3}$ Laboratório de Análises de Bacias e Petrofísica, UFPR, Cx. Postal 19027, Centro Politécnico \\ 81531-990 Curitiba, PR, Brasil \\ ${ }^{4}$ Instituto de Geociências, USP, Rua do Lago, 562 \\ 05508-080 São Paulo, SP, Brasil
}

Manuscript received on October 13, 2003; accepted for publication on October 13, 2004; contributed by ANTONIO C. ROCHA-CAMPOS*

\begin{abstract}
Striae and furrows found on the upper surfaces of three stratigraphically superposed decimetric beds of late Paleozoic lodgement tillite of the Itararé Subgroup in the northern Paraná Basin were engraved by ploughing of clasts and possibly also ice protuberances at the base of the glacier, on unconsolidated to partially consolidated sediment. Associated features indicate that the rheology of the bed varied from stiff during lodgement to soft and deformable during ploughing. Poor drainage of meltwater at the glacier-bed interface may have contributed to lower the strength of sediment to deformation.

The deformed interval was probably generated during a single glacial phase or advance of a glacier grounding in a marine or lacustrine water body. Changes in the dynamics of the glacier involving slow and fast flow were correlated respectively with alternation of deposition and erosion. The proposed model is analogous to that of lodgement till complexes from the Pleistocene of the northern hemisphere. Retreat of the glacier was probably fast, followed by settling of muds on top of the upper striated and furrowed surface, and progradation of deltaic sands during post-glacial time.
\end{abstract}

Key words: glacially striated surfaces, soft sediments, Itararé Subgroup, late Paleozoic.

\section{INTRODUCTION}

Surfaces bearing furrows and striae formed on unconsolidated sediments are relatively common features associated with diamictites and other rocks in pre-Pleistocene glacigenic successions (see Woodworth-Lynas and Dowdeswell 1994 for references).

* Member Academia Brasileira de Ciências Correspondence to: Antonio C. Rocha-Campos

E-mail: acrcampo@usp.br
In most localities the surfaces have been interpreted as resulting from the movement of a glacier across soft beds, being thus subglacial features. Similar to hard rock striated pavements, the presence of striated surfaces is usually taken as one of the best criteria for assigning a glacial origin to the associated beds (Hambrey and Harland 1981, Crowell 1999). Woodworth-Lynas and Dowdeswell (1994) have pointed that many examples of striated sur- 
faces described in the literature correspond to features formed by the mechanical scouring of floating ice on sea or lakebed and offer criteria for distinguishing between the two types of structures.

Soft sediment striated beds are herein designated surfaces, in contrast with hard rock striated pavements. The adjective striated is applied here in a broad sense to designate bedding planes bearing striae (positive and negative elements with relief up to few millimeters), furrows (negative features) and ridges (positive features) with relief of more than a few millimeters, of varied shapes, as well as other abrasional features.

We describe here an extensive striated surface formed on top of a diamictite probably representing a subglacial (lodgement) tillite at the basal part of the Itararé Subgroup (late Paleozoic), well exposed near São Luiz do Purunã, State of Paraná, on the southern flank of the Ponta Grossa arch (Paraná Basin). The locality was first briefly reported by Assine and Zanotto (1993). Additional field work in the area (Vesely and Assine 1999, Trosdtorf Jr. et al. 2003) showed that at least two other stratigraphically distinct, closely spaced $(\mathrm{dm})$ surfaces are partially exposed within the tillite. We interpret the features as of subglacial origin that is, generated by the repetitive sliding of a glacier on unlithified sediment.

Our survey of the literature showed that reports on multiple, soft sediment glacially striated surfaces similar to the ones here described are relatively rare in pre-Pleistocene glacigenic successions. O'Brien and Christie-Blick (1992), for example, described a series of six stratigraphically repeated, closely spaced (dm to $\mathrm{m}$ ) striated surfaces formed on glacial marine sandstone. The authors interpret that the striae were cut by the recurrently grounding glacier on glacial marine outwash. They assigned the features to a subglacial rather than to a floating ice origin in view of high consistency of orientations of striae on the different surfaces. Several intraformational, striated surfaces occurring on top of diamictite and sandstone of the Buckeye Formation in the Transantarctic Mountains of Antarctica were reported by Aitchison et al. (1988). Most of the surfaces are stratigraphically tens to hundreds of meters apart from each other and are typically overlain by boulder pavements. Only two surfaces at the top of the unit are as closely spaced (about $20 \mathrm{~cm}$ ) as the ones reported here. The striations were interpreted as due to glacial erosion by Aitchison et al. (1988), but an origin through scouring of soft sediment by floating ice has been proposed by Woodworth-Lynas and Dowdeswell (1994).

Other reports are by Rocha-Campos et al. (1997, 1999), who described multiple, soft sediment, furrowed and striated surfaces on top of shallow marine Proterozoic quartzite, directly overlain by diamictite of the Jequitai Formation in central Minas Gerais State, and on sandstone of the Curituba Formation, Northeastern Brazil, and by Trosdtorf Jr. et al. (2003), who described multiple striated surfaces on late Paleozoic fluvioglacial and glacimarine sandstones of the Itararé Subgroup (Paraná Basin, Southern Brazil). Close parallelism of the features and absence of lateral berms (Woodworth-Lynas and Dowdeswell 1994) in both localities, plus deformation of beds underlying the striations in the Paraná Basin suggest a subglacial origin for the striations under an oscillating grounded, glacier margin. In Northeastern Brazil features assigned to scouring by floating ice appear associated with subglacial striations (Rocha-Campos et al. 1997, 1999).

Characteristics that distinguish the surfaces at São Luiz do Purunã from other pre-Pleistocene localities are their occurrence on closely spaced beds of lodgement tillite which have similar textures and clast composition. These aspects may be related with glacier dynamics as discussed later.

To our knowledge, multiple, glacially striated surfaces have yet not been found in Pleistocene or Recent glacial deposits. The only example of an exceptionally well-preserved single sand bed bearing striae and depositional features formed beneath a sliding glacier is described by Clark and Hansel (1989) from the Pleistocene of Illinois. They assign the preservation of the sand bed to syn-sedimentary (subglacial) carbonate cementation. Intraforma- 
tional, glacially striated surfaces thus do occur in recent and Pleistocene deposits, but, as a rule, they do not become easily exposed, and are mostly destroyed by erosion. Striated and furrowed surfaces described may be equivalent to sharp, planar discontinuities (unconformities) separating multiple, thin till units described by Eyles et al. (1982) and related to variation in deposition of lodgement till.

The intrabasinal nature of most of the ancient glacigenic deposits, on the other hand, implies continuous subsidence, and accumulation of younger sediments that may include post-glacial transgressive beds, followed by diagenesis. Subglacially compacted, striated beds are also often impermeable and subject to cementation and hardening during weathering (Eyles 1993). Several authors (Savage 1972, Visser and Hall 1984, von Brunn and Marshall 1989, Visser 1990) have raised the question of the potential preservation of soft sediment, striated and grooved surfaces in late Paleozoic glacigenic successions in the context of an active glacial environment. This aspect will be briefly considered later in this paper.

In view of their rarity in the geological record, exposures of multiple, glacially striated, soft sediment surfaces offer an insight into subglacial erosional and depositional processes and the behavior of former glaciers. They provide observations of interactions of glaciers and unlithified (deformable) substrata that may have occurred under the Gondwana ice sheets.

\section{LITHOSTRATIGRAPHY AND PALEOENVIRONMENTAL SETTINGS}

The striated surfaces crop out in an ample, horizontal area, a few meters southwest of the road BR-277, at km 136, east from São Luiz do Purunã, PR, on the south flank of the Ponta Grossa arch, Paraná Basin (Fig. 1).

The Fig. 2 is a schematic stratigraphic section of the outcrop area. The main striated surface occurs on the top of a $5 \mathrm{~m}$ thick, upper, tabular, diamictite bed. Two other partially exposed striated surfaces occur at two different levels, decimeters apart, within the diamictite. The total area of the latter two is unknown. Except for these discontinuities, the diamictite seems homogeneous along its entire thickness.

Strata underlying the diamictite consist of a 10$15 \mathrm{~m}$ thick sequence of interbedded, decimetric layers of fine, massive sandstone and diamictite. Clasts (up to $15 \mathrm{~cm}$ in diameter) dispersed in the sandstone may correspond to dropstones. The upper contact of these beds with the diamictite was not observed. The Itararé succession rests unconformably on sandstone of the Furnas Formation (Devonian).

Bigarella et al. (1967) assigned extensive glacial striations found on the Devonian Furnas Formation, and on thin (decimeters to few meters) reddish diamictite and sandstone beds that overly the Furnas, in the basal Itararé Subgroup exposed on southern Ponta Grossa arch, to two successive "glaciations", respectively, Rio do Salto and Cancela. The direction of movement of glacier in both cases was northward. Trosdtorf Jr. (unpublished data) however, related the features to two successive advances of the late Paleozoic Paraná glacial lobe.

The diamictite is dark reddish, silty-clayey, well consolidated, and crudely bedded and includes rare, thin, discontinuous partings of tightly folded and faulted, stratified, fine conglomeratic sandstone. Clasts of varied composition (mainly Precambrian metamorphic and igneous rocks), angular to well rounded, ranging in size from pebbles to boulders (up to $40 \mathrm{~cm}$ ) are relatively abundant. Striations and furrows affect the upper $4-10 \mathrm{~cm}$ of the diamictite, corresponding to the depth of the features. Small planar clast clusters with beveled clasts and isolated, faceted and striated clasts occur in the lower portion of the diamictite bed. These features are described in detail below. The above set of characteristics seems compatible with the interpretation of the diamictite as a subglacial (lodgement) tillite.

Beds above the diamictite comprise two coarsening-thickening upward cycles, each around $10 \mathrm{~m}$ thick, of fine to coarse sandstone and interbedded mudstone (Figs. 2 and 3). The main 


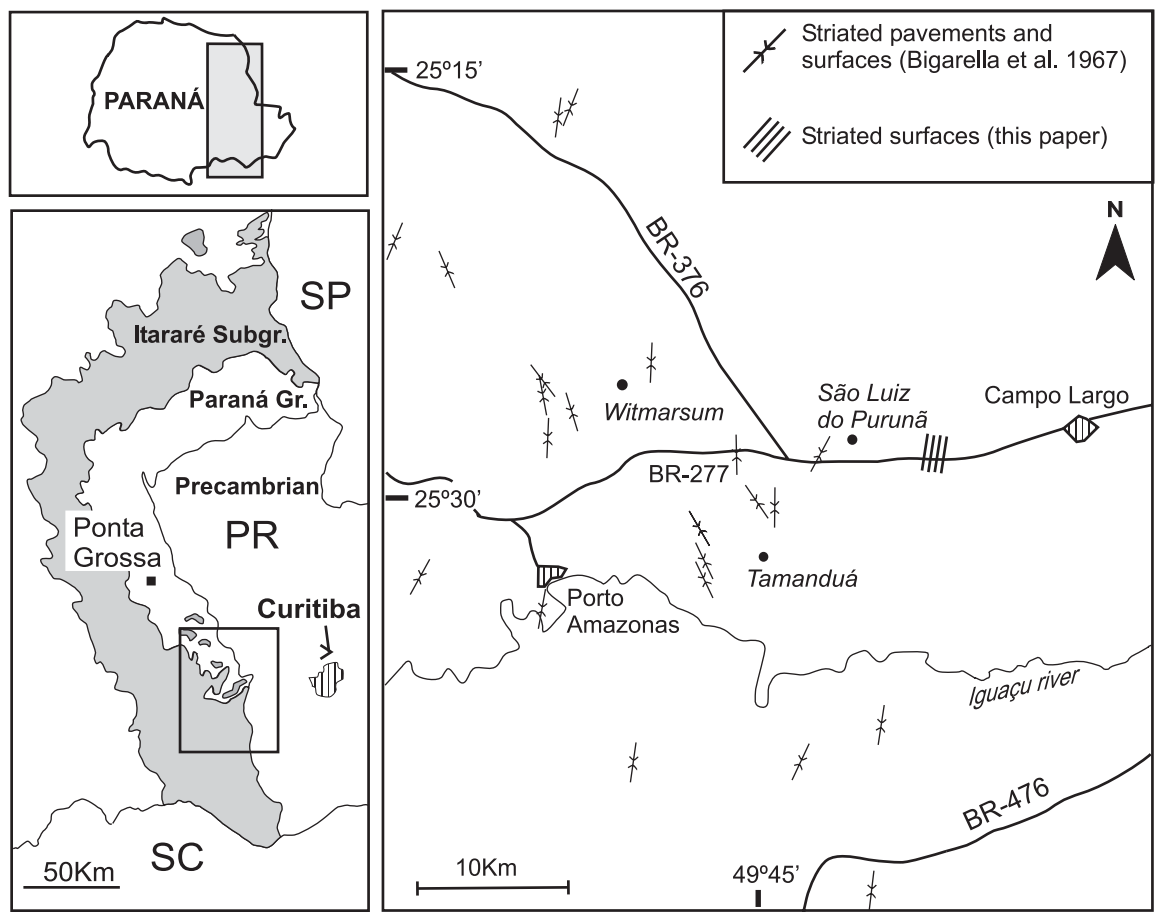

Fig. 1 - Location of study area. SP: São Paulo; PR: Paraná; SC: Santa Catarina.

striated surface is directly overlain by a lower, up to $3 \mathrm{~m}$ thick mudstone layer. Mudstone intercalations become thinner toward the upper part of each cycle where amalgamated beds of sandstone predominate. Sigmoidal cross-bedding, climbing ripple cross-lamination, load and soft-sediment deformation are frequent in the sandstone. Dropstones seem to be absent in beds above the diamictite. Paleocurrents in the sandstone flowed in average toward west (Fig. 2), normal to the local sense of movement of glacier. We interpret this part of the section as made up of deltaic sands intercalate with prodeltaic muds.

The lithofacies succession in the upper part of the section examined at São Luiz do Purunã (Fig. 2) seems thus to record several episodes of subglacial deposition of layers of lodgement tillite subsequently furrowed and striated. These are possibly related to phases of slow or fast ice flow respectively (Bennett and Glasser 1997). Final retreat of the glacier was accompanied by accumulation of subaquatic muds and progradational deltaic sands.

A question that arises at the studied outcrop is whether the glacier that deposited the lodgement tillite and produced the striations moved in a glacial terrestrial environment, post-glacially flooded by a water body, or whether it reached the margin, and entered grounded into an already existing lacustrine or marine basin. Occurrence of extensive striated pavements or surfaces in pre-Pleistocene successions has often been taken as indicative of glacial terrestrial setting (e.g. Bigarella et al. 1967, Savage 1972, von Brunn and Marshall 1989). Acoustic imaging of glaciated continental margins (Davies et al. 1997), shows a profusion of subglacial features (lineations, drumlins, flutes, glaciotectonic), that demonstrates that subglacial processes continue under grounded ice. These are, however, megascale features. Features of the dimensions of the ones described here are probably below the resolution of acoustic methods.

The Itararé Subgroup beds examined are not fossiliferous, and thus the paleoenvironment of the rocks has to be interpreted on the basis of lithofacies characteristics and distribution in analogous recent glacial environments. 


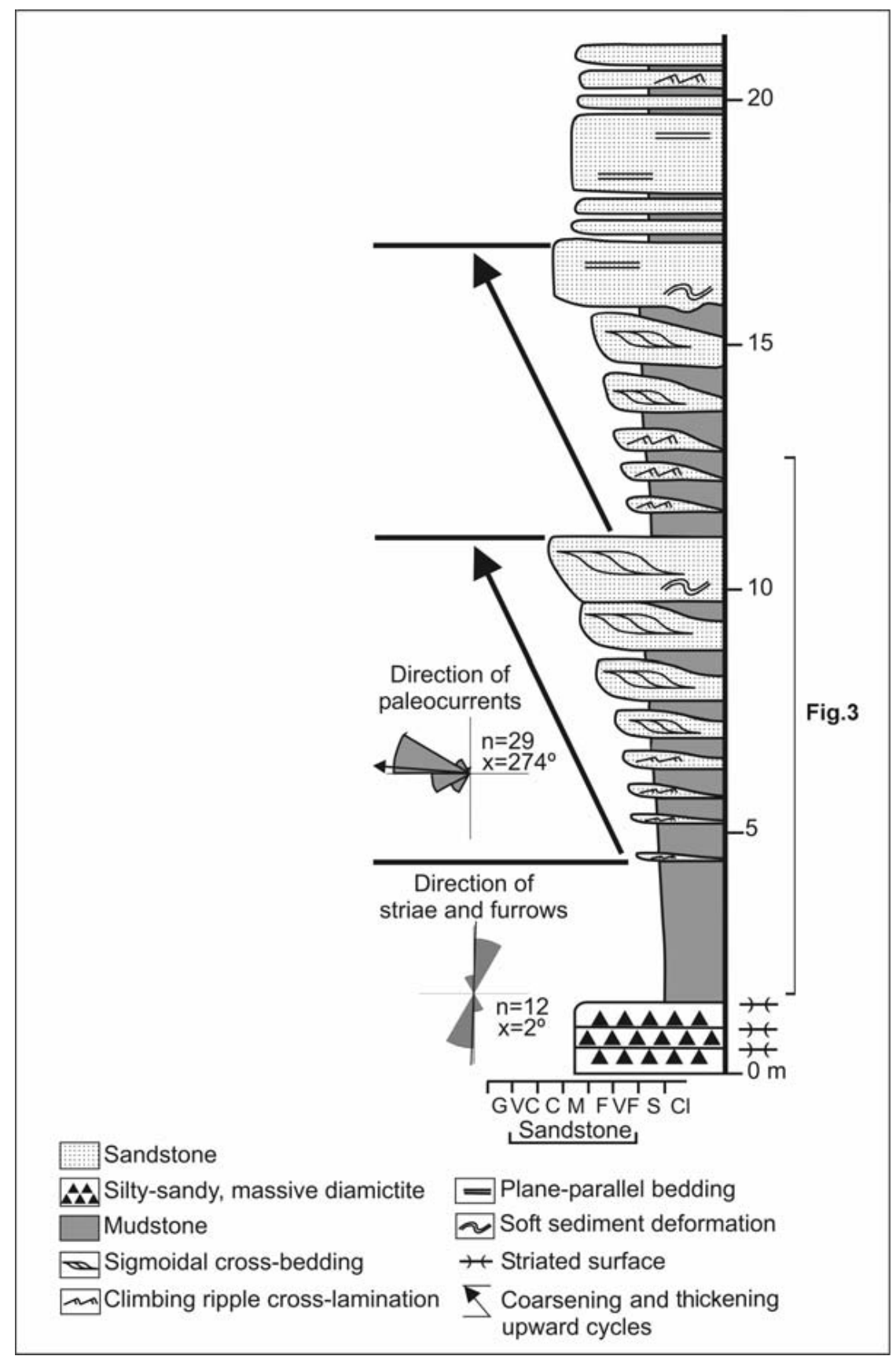

Fig. 2 - Stratigraphic section of basal Itararé Subgroup beds at São Luiz do Purunã, PR.

The diamictite bearing the striated surfaces is intercalated between beds of probable subaquatic facies (stratified sandstone below and laminated mudstone above) in the outcrop studied (Fig. 2). This facies relation suggests a probable penecontemporaneity in the deposition of striated diamicton, muds and sands. Other features that are considered as characteristic of gravity-driven deformation that commonly occur associated with proglacial subaqueous beds (Eyles 1993) are missing.

Geological preservation of the extensive upper surface would probably be more prone to occur subaquatically. Reimnitz and Barnes (1974) comment that floating ice scours cut in marine beds are often modified and smoothed by bottom currents unless protected by deposition of fine sediments. 


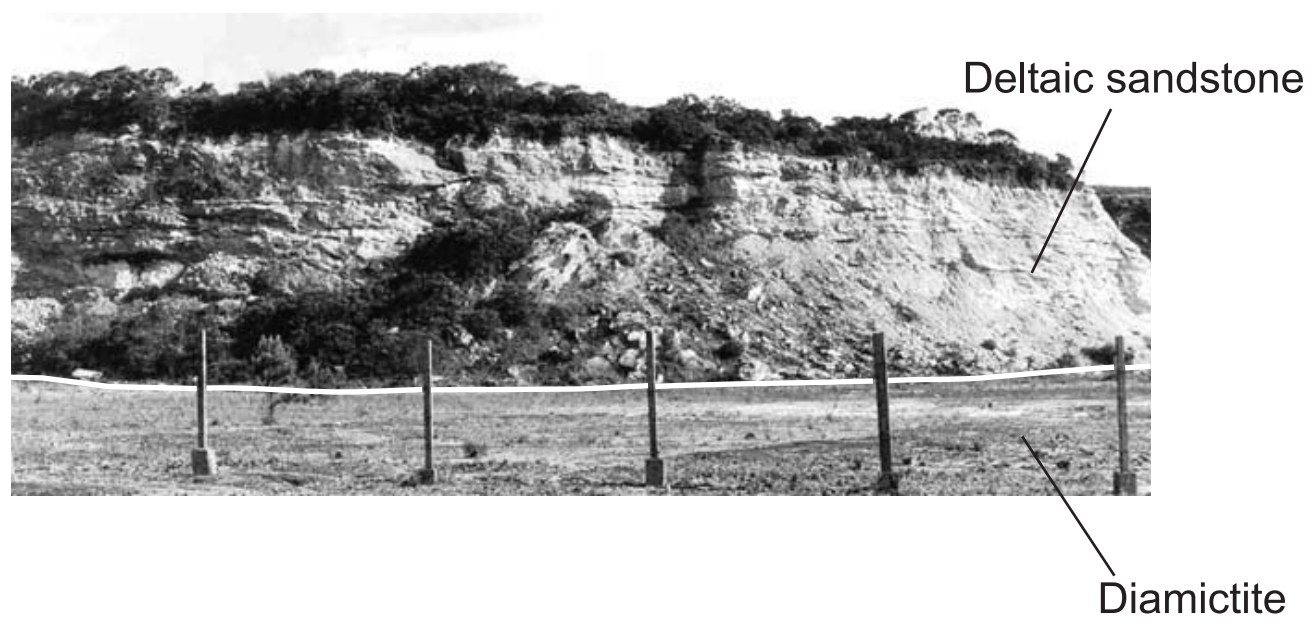

Fig. 3 - Deltaic sandstone and mudstone overlying the diamictite. Contact marked by white line.

We thus envisage the paleoenvironmental setting at the present locality as corresponding to a water body (lacustrine/ marine) into which the glacier advanced grounded. In analogy with sedimentary processes described by Powell (1983) in glacialstuarine environment, a combination of fast retreat of the glacier margin to a position away from the water associated with rising sea level, and lateral changes in the site of deposition in the basin could have resulted in the accumulation of fine-grained sediments (mud drape) over furrowed and striated till. Absence of dropstones in the beds above the diamictite may indicate that the glacier had lost contact with the water and/or no calving of bergs was happening or even that they were moving rapidly away (Everhoi et al. 1980, Molnia 1983). We may speculate that progradation of the outwash delta was triggered by post-glacial isostatic uplift of the basin margin. Coarse glaciclastic deposits (subaqueous outwash) that could indicate ice contact however were not found. Alternatively, deposition of the deltaic package may represent a later event when marine processes were dominant and glacial influence was minimum.

Lithofacies succession in the studied outcrop can be compared to fourth/ fifth order cycles inserted in the third order sequences described in the Itarare Subgroup and interpreted as glacio-eu-isostatically controlled (Canuto et al. 2001).

\section{STRIATED SURFACES}

The following description is mainly based on the uppermost and better exposed striated surface at São Luiz do Purunã (Fig. 2). The lower ones are of limited exposure and presumably less extensive.

The surface crops out almost continuously over an area of at least $40 \mathrm{~m}$ by $30 \mathrm{~m}\left(1,200 \mathrm{~m}^{2}\right)$ being covered by striae, furrows and ridges, essentially rectilinear and parallel, oriented in average around $\mathrm{N} 2^{\circ}$ (Fig. 4A). Individual larger furrows and ridges may reach at least $11 \mathrm{~m}$ in length. Width of furrows is somewhat irregular due to the textural heterogeneity of the excavated diamicton, and range from centimeters to around $55 \mathrm{~cm}$. Their section varies from shallow " $U$ '"-shaped (wider furrows) to " $\mathrm{V}$ "'-shaped (narrower furrows) with depths up to $10 \mathrm{~cm}$. Ridges between furrows, decimetric (30$55 \mathrm{~cm}$ ) up to $1.5 \mathrm{~m}$ wide, have also low, inverted ' $U$ ''-shaped section with flat tops or more rounded section (Fig. 4B).

Striae and small furrows occur inside larger furrows and on ridges. Striations may be narrow and shallow at one or both ends; some have accumulated ridges or prows of sediment at one end (Figs. 4A and B). The glacial features are intersected by several differently oriented groups of parallel furrows, artificially excavated during road construction (Fig. 4A). The former can be easily distinguished 

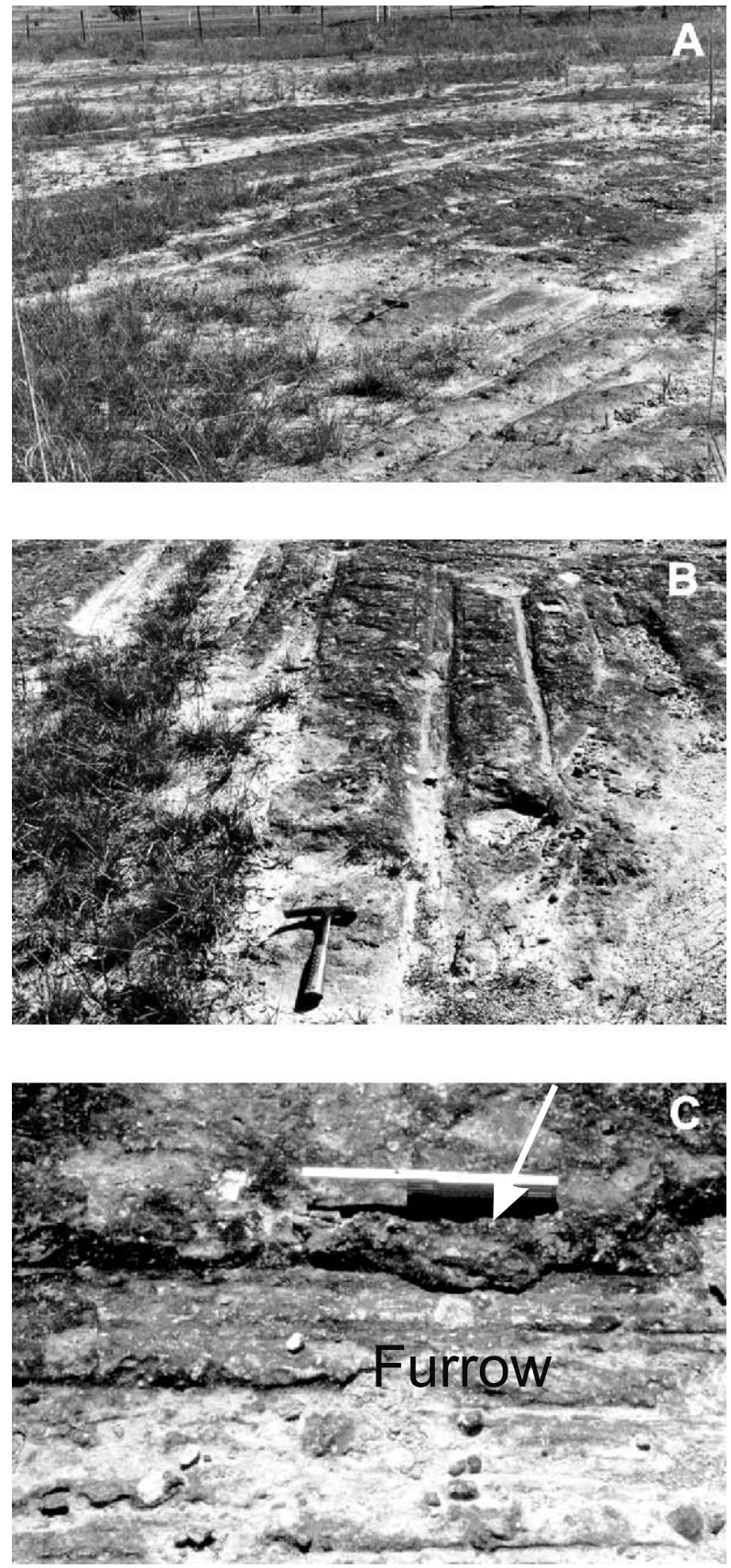

Fig. 4 - A) General view toward NW of the upper stratified and furrowed surface. Sense of glacier movement toward right; B) Series of long furrows and flat topped ridges. Striae occur on bottom of furrows and top of ridges; sense of glacier flow was toward top (N); C) flap-like layer of diamictite (arrow) covering striae inside furrow (scale: $35 \mathrm{~cm}$ ). by being isoriented and internally striated. Orientations of features on the lower surfaces differ only slightly from those on the main one, but are less well preserved.

A series of other features of the striated surfaces confirm their soft-sediment nature and give indication on subglacial processes associated with the generation of the striae. They are:

a) Slumped diamicton. Small, flap-like layers of diamictite cover striae inside furrows. They obviously represent masses of diamicton that flowed down from adjacent ridges (Fig. 4C).

b) Sediment prows. Concentric, curved ridges of diamictite around one end of clasts suggesting that sediment has been pushed in front of them when being ploughed into the underlying diamicton and finally lodged (Fig. 5A). Isolated prows may have been produced by the same mechanism, though not associated with lodgement of the ploughing clasts. Some prows may have been produced by ice protuberances under the sliding glacier.

c) Curved, oblique furrows. A few smaller furrows are curved and are oblique to the main orientation of features on the surface. These may be formed by rotation and change in the trajectory of a moving clast or by a clast with an irregular keel (Clark and Hansel 1989). (Fig. 5B.)

d) Linear accumulation of sediment in the shadow of clasts. One example of small, dm long feature found inside a curved furrow may represent a type of crag and tail feature (Fig. 5B). Larger ridges of diamictite, up to $55 \mathrm{~cm}$ wide, about $15 \mathrm{~cm}$ high and several meters long, with flat, striated tops, found on the lee side of boulders are remindful of flutes (Fig. 4B). Similar features in front of Turtman Glacier (Switzerland) have been called miniflutes and assigned to seasonal advances of the debris-free glacier on pre-deposited till by van der Meer (1997). Association of striations with evidence of 
lodgement at São Luiz do Purunã is more suggestive of an origin predominantly through the ploughing action of subglacial clasts. Relative abundance of clasts in the diamictite at the outcrop studied suggests that they were an important component in the basal debris zone of the glacier;

e) Embedded clasts. Clasts transported at the base of the glacier ploughed the soft till until they became firmly anchored in it when frictional resistance of the sediment exceeded the drag imposed by the sliding glacier (Boulton 1979).

Contrasting with these, features in the lower zone of the diamictite seem to point to stiffer conditions in the till. These are planar clusters of clasts with beveled tops and clasts with faceted and striated tops not associated with prows that appear immersed in the diamictite matrix on the bottom of furrows. We consider that truncation of resistant rocks by the glacier would only be possible if the clasts were embedded in a stiff, non-deformable bed.

Clusters of clasts are tightly packed and have their long axes trending $\mathrm{N} 20^{\circ}$, being thus roughly parallel with the general orientation of furrows and striae. They could correspond to a type of subglacial boulder pavement (Fig. 5C).

Sediments prows and linear concentrations of sediment allow the interpretation of the sense of movement of the glacier in the area that was toward north, coinciding with the general trend of late $\mathrm{Pa}$ leozoic ice movement in the southern flank of the Ponta Grossa arch (Bigarella et al. 1967).

\section{ORIGIN OF THE SURFACES}

Furrows and striae on the studied surface have been probably excavated into non-lithified bed (till) mainly by subglacial plowing of the diamicton by keels of clasts being transported at the sole of a sliding glacier. It is possible that subglacier ice protuberances also contributed to this process. Strong parallelism of striations over the large exposed area, absence of berms and presence of the above-
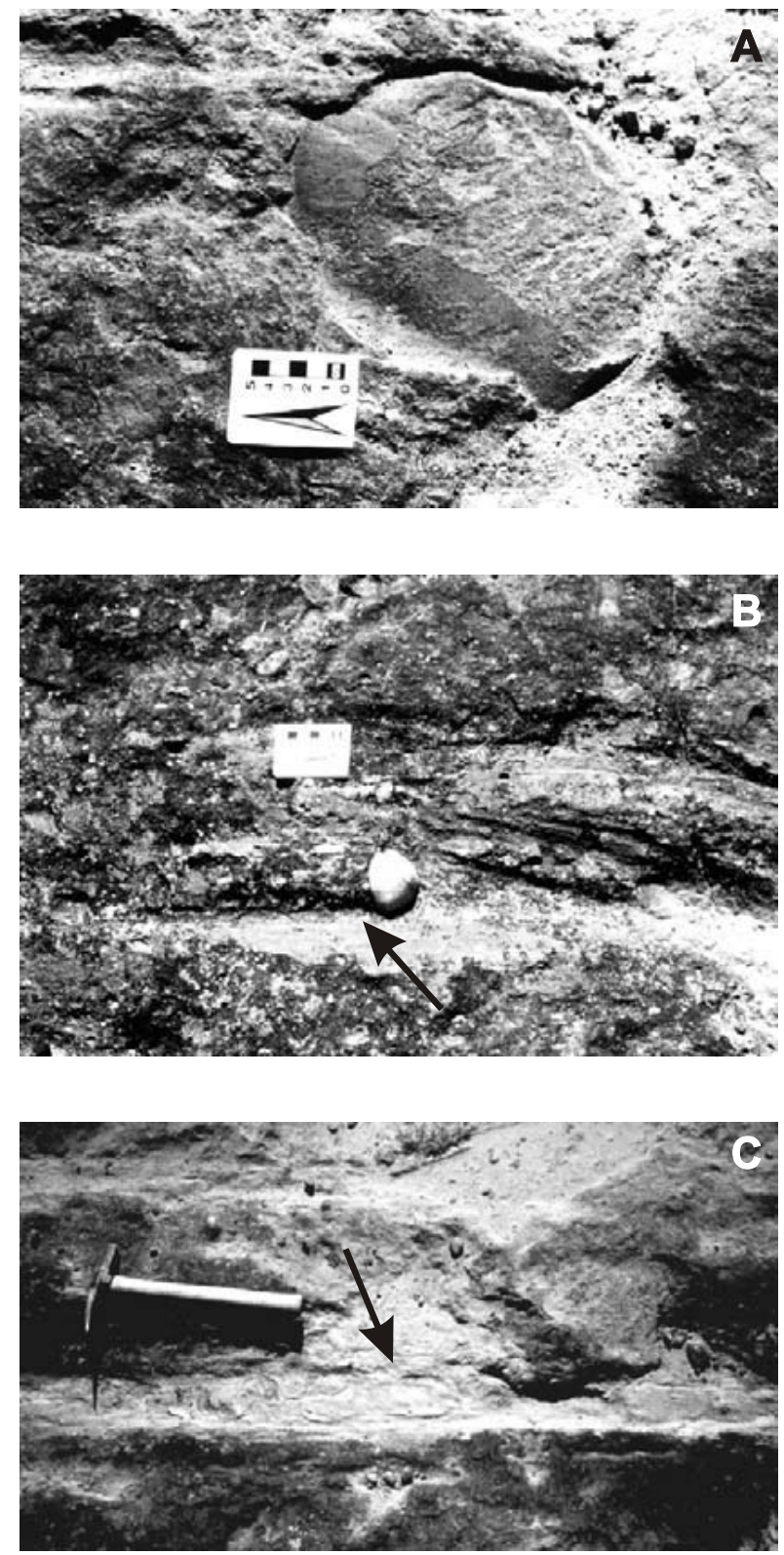

Fig. $5-$ A) Lodged boulder inside furrow bearing striae on beveled top; rough area of clast was broken during exhumation of outcrop; B) curved furrows and striae; note linear concentration of diamictite on the lee side of clast (arrow); C) aligned lodged clasts with truncated tops (arrow) inside furrow (boulder pavement).

described features rule out the possibility of origin by scouring of floating ice.

A similar origin involving ploughing is proposed by Clark and Hansen (1989) for a soft sediment striated surface from the Pleistocene of Illinois, but developed on glaciofluvial sand. As in 
our case, striations here are associated with sediment prows, linear grooves and striated clasts that the authors take as evidence of subglacial lodgement. Clark and Hansen (1989) point out that current subglacial depositional models establish that a "stiff" bed on which the englacial debris can be accreted is a necessary requirement for lodgement to occur (Boulton 1982, Eyles and Menzies 1986, Eyles 1993, Bennett and Glasser 1997). They then propose in the case of the Illinois surface that soft bed condition could have been generated in response to strong stress concentration at the clast-bed contact.

At the Paraná Basin locality, however, the glacier moved on top of soft silty-clayey diamicton (Fig. 2). There is no evidence of presence of relatively thick deformed bed produced by pervasive shear stress (Boulton and Hindmarsh 1987, Alley et al. 1987). On the contrary, deformation in our case is usually associated with ploughing clasts, being restrict to the upper $10-15 \mathrm{~cm}$ of the tillite and underlain by a more stiff, less deformable horizon of lodgement till. Rare shoestring lenses of meltout sands intercalated in the diamictite may indicate poor subglacial drainage at the glacier-bed interface, high pore water pressure and relatively low shear strength of the till.

Several authors (Beget 1986, Brown et al. 1987, Fischer and Clarke 1994, Tulaczyk 1999, Tulaczyk et al. 2001) have proposed that ploughing of clasts and of ice protuberances at the bottom of ice facilitate fast sliding of a glacier over deformable sediments. The common occurrence of soft sediment furrowed and striated surfaces in the late Paleozoic glacigenic beds of Brazil suggests that ice sliding by ploughing was a common mechanism for the displacement of the Gondwana glaciers.

The small linear accumulation of sediments and flute-like ridges found on the striated surface suggest that other erosional and depositional subglacial processes may also have been active at São Luiz do Purunã, involving the flow or deformation of sediment around obstacles formed by the presence of a boulder. The first features are also remindful of hairpin erosional marks assigned to the action of horseshoe vortices of meltwater around an obstacle (Shaw 1998). Hairpin marks are, however, entirely abrasional features that have been reported generally associated with subglacially hard bedrock. Surface of flute-like features bear striae indicating that they were molded in contact with the glacier (Fig. 4B). Although basal meltwater did probably existed at the interface between the glacier and the unconsolidated bed, landforms indicative of strong meltwater action, such as sinuous mega-channels, are missing.

Interpretation of the local succession (Fig. 2) in terms of glacial stratigraphy presents some difficulties and a provisional explanation is here advanced. The apparent rheology of the diamictite, as discussed above, suggests that each bed of lodgement tillite overlain by the furrowed and striated surfaces may record transitional episodes of deposition of subglacial till followed by erosion by ploughing. These could correspond respectively to a change from conditions of slow to fast moving ice (Bennett and Glasser 1997). The tillite beds are of the same facies both texturally as well as in clast composition and have been deposited by a glacier flowing consistently toward north.

In our view, the above circumstances may be more easily explained if we consider the studied tillite sequence as resulting from a single glacial phase or advance, during which changes in the glacier flow or dynamics took place leading to alternation between subglacial deposition and erosion. The concept is analogous to the model of lodgement till complex proposed by Eyles et al. (1982) for Pleistocene lodgement till sequences (lodgement till complexes) of England. Accordingly, the intraformational striated surfaces at São Luiz do $\mathrm{Pu}$ runã would be equivalent to the sharp planar discontinuities (unconformities) that separate Pleistocene lodgement till units.

In this context, preservation of the soft sediment striated surfaces that occur internally in the diamictite at São Luiz do Purunã may be explained by the deposition of a layer of diamicton on top of each of them. Covering by subaqueous mud would, by 
its turn, protect the uppermost surface from subsequent erosion. A similar explanation was advanced by Trosdtorf Jr. et al. (2001) for the preservation of other multiple, soft sediment, striated surfaces from the base of the Itararé Subgroup, in Palmeira, some $30 \mathrm{~km}$ west from the present locality.

\section{FINAL REMARKS}

Closely spaced, stratigraphically repeated striated and furrowed surfaces formed on top of late Paleozoic (Itararé Subgroup) beds of lodgement tillite, well exposed in northern Paraná Basin, Brazil, allow examination of subglacial erosional and depositional features indicative of processes that occurred in the interface between the Gondwana glacier flowing on soft, deformable bed. The multiple striated surfaces were generated mostly by ploughing of unlithified diamicton by clasts transported at the base of a warm based glacier on top of lodgement till beds. The relative fine-grained diamicton and presence of meltwater probably provided a weak interface between the bed and overlying glacier leading to limited deformation and possibly fast sliding.

The local tillite stratigraphy records a history of an advance of a grounded glacier into a waterfilled basin. Variation in the velocity of glacier flow from slow to fast was associated with deposition of lower layer of lodgement till and erosion of an upper soft bed and formation of striated surfaces. The proposed explanation is analogous to the model of lodgement till complex discussed by Eyles et al. (1982). Retreat of the glacier was probably fast, followed by accumulation of muds on top of till. Post-glacial history is marked by the progradation of wedge bodies of deltaic sands into the lacustrine or marine basin.

Subglacial features associated to multiple striated surfaces preserved in studied locality are rarely seen in the geological record and offer a view of processes associated with a warm based glacier moving on a soft and deformable bed, such as ploughing. We believe these features in the pre-Pleistocene record deserve additional study.

\section{ACKNOWLEDGMENTS}

We thank Ian McReath for kindly revising the English language. This research had the financial support of Fundação de Amparo à Pesquisa do Estado de São Paulo (FAPESP Proc. 2000/12125-2 and Proc. 98/02183-3).

\section{RESUMO}

Estrias e sulcos encontrados sobre três camadas decimétricas, estratigraficamente superpostas, de tilito de alojamento neopaleozóico do Subgrupo Itararé, na porção norte da Bacia do Paraná, foram formados por aração de clastos e, possivelmente, por protuberâncias de gelo, na base da geleira. Feições associadas indicam que a reologia do sedimento variou de rígido, durante o alojamento, a inconsolidado e deformável durante a aração. A baixa drenagem da água de degelo na interface geleira-substrato pode ter contribuído para reduzir a resistência do sedimento à deformação.

A sucessão acima foi gerada provavelmente durante uma única fase glacial ou avanço de geleira sobre corpo de água marinho ou lacustre. Mudanças na dinâmica da geleira envolvendo fluxos lento e rápido corresponderam, respectivamente, a alternâncias entre deposição e erosão. O modelo proposto é análogo ao de complexos de till de alojamento do Pleistoceno do hemisfério do norte. $\mathrm{O}$ recuo da geleira foi provavelmente rápido, seguido pela deposição de lama acima da superfície estriada e sulcada superior, e progradação de ciclos de arenitos deltáicos durante a época pós-glacial.

Palavras-chave: estrias glaciais, sedimentos inconsolidados, Subgrupo Itararé, Neopaleozóico.

\section{REFERENCES}

Aitchison JC, Bradshaw MA And Newman J. 1988. Lithofacies and origin of the Buckeye Formation: Late Paleozoic glacial and glaciomarine sediments, Ohio Range, Transantarctic Mountains, Antarctica. Palaeogeogr Palaeoec 64: 93-104.

Alley RB, Blankenship DD, Bentley CR And Rooney ST. 1987. Till beneath ice stream B 3. Till deformation: evidence and implications. J Geoph Res 92: 8921-8929. 
Assine ML And Zanotto OA. 1993. Excursão I: Bacia do Paraná. In: Simpósio Sul-Brasileiro DE Geologia, 5., Curitiba, 1993. Roteiro de Excursão, Curitiba: Sociedade Brasileira de Geologia, 4 p.

BEGET JE. 1986. Modeling the influence of till rheology on the flow and profile of the Lake Michigan lobe, southern Laurentide ice sheet, U.S.A. J Glaciol 32: 235-241.

Bennett MR and Glasser NF. 1997. Glacial Geology, ice sheets and landforms, New York: John Wiley and Sons, $364 \mathrm{p}$.

Bigarella JJ, Salamuni R and Fuck RA. 1967. Striated surfaces and related features developed by the Gondwana ice sheets (State of Paraná, Brazil). Palaeogeogr Palaeoec 3: 265-276.

Boulton GS. 1979. Processes of glacial erosion on different substrata. J Glaciol 23: 15-38.

Boulton GS. 1982. Subglacial processes and the development of glacial bedforms. In: DAVIDSON-ARNOTT R ET AL. (Eds.), Glacial, Glaciofluvial and Glaciolacustrine Systems, Norwich: Norwich Geo-Books, p. 1-31.

Boulton GS and Hindmarsh RCA. 1987. Sediment deformation beneath glaciers: rheology and geological consequences. J Geophys Res 92: 9059-9082.

Brown NE, Hallet B AND Booth DB. 1987. Rapid soft bed sliding of the Pudget glacial lobe. J Geophys Res 92: 8985-8997.

Canuto JR, Santos PR dos and Rocha-Campos AC. 2001. Estratigrafia de seqüências do Subgrupo Itararé (Neopaleozóico) no leste da Bacia do Paraná nas regiões sul do Paraná e norte de Santa Catarina, Brasil. Rev Brasil Geocienc 31: 107-116.

Clark PU and Hansel AH. 1989. Clast ploughing, lodgement and glacier sliding over a soft glacier bed. Boreas 18: 201-207.

Crowell JC. 1999. Pre-Mesozoic Ice Ages: Their Bearing on Understanding the Climate System. Geol Soc Am Mem 192: 106.

Davies TA, Bell T, CoOper AK, Josenhans H, Polyak L, Solheim A, Stoker MS And Stravers JA. 1997. Glaciated Continental Margins: An Atlas of Acoustic Images, London: Chapman and Hall, 315 p.

Drewry DJ. 1987. Glacial Geologic Processes. London: Edward Arnold, 276 p.
Everhoi A, Liestol O AND NAGy J. 1980. Glacial erosion, sedimentation and microfauna in the inner part of Kongsfjorden, Spitsbergen. Norsk Polarinstitut Skriffer 172: 33-61.

EYLES N. 1993. Earth's glacial record and its tectonic setting. Earth-Sci Rev 35: 1-248.

Eyles N ANd MenZIES J. 1986. The Subglacial Landsystem. In: Eyles N. (Ed.), Glacial Geology, Oxford: Pergamon Press, p. 19-70.

Eyles N, Sladen JA AND Gilroy S. 1982. A depositional model for stratigraphic complexes and facies superposition in lodgement tills. Boreas 11: 317-333.

Fischer UH AND Clarke GKC. 1994. Ploughing of subglacial sediment. J Glaciol 40: 97-106.

Hambrey MJ AND HaRland WB. 1981. Earth's prePleistocene Glacial Record, Cambridge: Cambridge University Press, 1004 p.

Molnia BF. 1983. Subarctic glacial-marine sedimentation: a model. In: MoLNIA BF. (Ed.), Glacial marine sedimentation, New York: Plenum Press, p. 95-144.

O'Brien PE and Christie-Blick N. 1992. Glacially grooved surfaces in the Grant Group, Grant Range, Canning Basin and the extent of Late Palaeozoic Pilbara ice sheets. J Aust Geol Geophys 13: 87-92.

Powell RD. 1983. Glacial-marine sedimentation process and lithofacies of temperate tidewater glaciers, Glacier Bay, Alaska. In: Molnia BF. (Ed.), Glacial marine sedimentation, New York: Plenum Press, p. $185-232$.

Reimnitz E And Barnes PW. 1974. Sea ice as a geological agent on the Beaufort Sea shelf of Alaska. In: Rudy JC ANd SATER JE. (Eds.), The coast and shelf of the Beaufort Sea, Calgary: Arctic Institute of North America, p. 301-353.

Rocha-Campos AC, Cruz FE, Sato PES and Saito MM. 1997. Late Paleozoic glacial and floating ice striated surfaces in northeastern Brazil. An Acad Bras Cienc 69: 271.

Rocha-CAmpos AC, Santos PR dos and Canuto JR. 1999. Multiple, glacially striated, soft sediment surfaces in the late Paleozoic and Proterozoic of Brazil. An Acad Bras Cienc 71: 841.

SAVAGE NM. 1972. Soft-sediment glacial grooving of Dwyka age in South Africa. J Sediment Petrol 42: 307-308. 
SHAw J. 1998. Hairpin erosional marks, horseshoe vortices and subglacial erosion. Sediment Geol 91: 269-283.

Trosdtorf JR I, Rocha-CAmpos AC, Tomio A, SAntos PR dos AND CANUTO JR. 2001. Origin and preservation of stratigraphically repeated, glacially striated surfaces in the Itararé Subgroup (late Paleozoic) in Palmeira, State of Paraná. An Acad Bras Cienc 73: 467-468.

Trosdtorf Jr I, Rocha-Campos AC, Tomio A AND SANTOS PR Dos. 2003. Late Paleozoic landforms of glacial erosion and glacial geology on the southern flank of the Ponta Grossa arch, Paraná Basin Brazil. In: LATinAmerican Congress of SEDIMENTOLOGY, 3., Belém, Proceedings, Belém: Museu Paraense Emílio Goeldi; UFPA, p. 304-306.

TulaczyK S. 1999. Ice sliding over weak, fine-grained tills: dependence of ice-till interactions on till granulometry. Geol Soc Am Special Paper 337: 159-177.

Tulaczyk S, Sherer RP and Clark CD. 2001. A ploughing model for the origin of weak tills beneath ice streams: a qualitative treatment. Quatern Int 86: 59-70.

VAN DER MEER JJM. 1997. Short-lived streamlined bedforms (annual small flutes) formed under clean ice, Turtmann Glacier, Switzerland. Sediment Geol 111: 107-118.
Vesely FF AND Assine ML. 1999. Superfícies estriadas pelo movimento de geleiras sobre substratos não-litificados: exemplos no Grupo Itararé, Estado do Paraná. In: Simpósio de Geologia do SudesTE, 6., São Pedro, Boletim de Resumos, São Pedro, SBG, $52 \mathrm{p}$.

VISSER JNJ. 1990. Glacial bedforms at the base of the Permo-Carboniferous Dwyka Formation along the western margin of the Karoo Basin, South Africa. Sedimentology 37: 231-245.

VisSER JNJ AND HALl KJ. 1984. A model for the deposition of the Permo-Carboniferous Kruitfontein boulder pavement and associated beds, Elandsvlei, South Africa. Trans Geol Soc S Afr 87: 161-168.

von Brunn V and Marshall CGA. 1989. Glaciated surfaces and the base of the Dwyka Formation near Pietermaritzburg, Natal. S Africa J Geol 92: $420-426$.

WoOdworth-Lynas CMT AND Dowdeswell JA. 1994. Soft-sediment striated surfaces and massive diamicton facies produced by floating ice. In: DEYNOUX M ET AL. (Eds.), Earth's Glacial Record, Cambridge: Cambridge University Press, p. 201-259. 